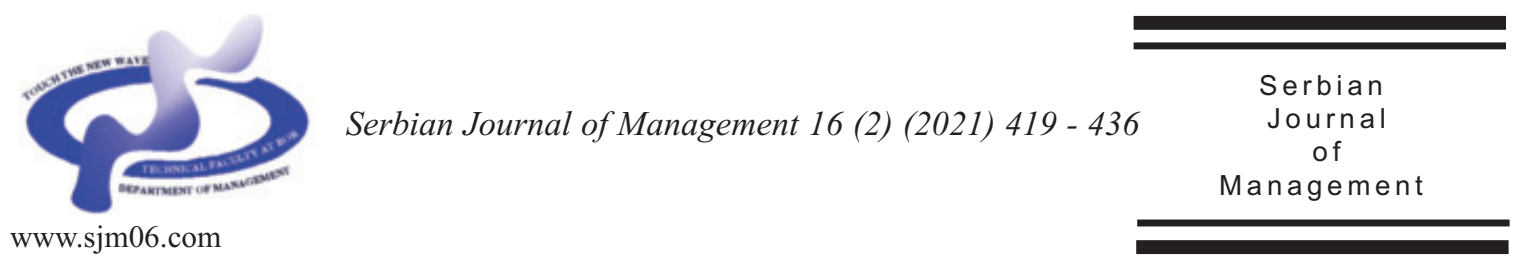

\title{
TRENDS, RISKS AND PROSPECTS FOR INDUSTRIAL COMPLEX DEVELOPMENT OF SOUTH OF RUSSIA IN NEW ECONOMIC REALITIES
}

\author{
Inna V. Mitrofanova ${ }^{a, b}$, Olga A. Chernovac, Victoria V. Batmanova ${ }^{\text {b* }}$ \\ and Oksana Yu. Trilitskayab

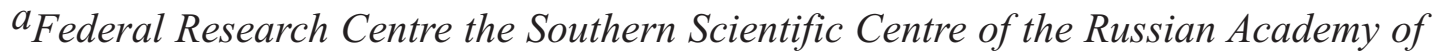 \\ Sciences (SSC RAS), Rostov-on-Don, 344006, Russia \\ $b_{\text {Volgograd State University, Volgograd, 400062, Russia }}$ \\ ${ }^{c}$ Southern Federal University, Russian Information-Analytic and Research Water Economy \\ Centre, Rostov-on-Don, 344006, Russia \\ (Received 05 October 2020; accepted 25 February 2021)
}

\begin{abstract}
Events caused by complex crisis which became evident in regional economies as a result of the spread of COVID-19 have affected the manufacturing industry of the South of Russia. The purpose of this article is to identify and analyse the prospects for the sustainable development of industry in the South of Russia in the context of new economic trends. The methodological basis of the study is founded on the theory of shocks, which made it possible to place at the center of the system of causeand-effect relationships a set of factors in business activity decrease, which are considered as shocks that form new development trends. The analysis revealed the presence of problems of production interruptions and break of supply chains, reduction in resource flows, as well as a decrease in effective demand for industrial products. According to the opinion of the authors, the prospects for the development of the industrial complex of the region are associated with the balance of market self-regulation and government regulation, and are also determined by the accumulated potential of the regional industry and available adaptive capabilities.
\end{abstract}

Keywords: industrial complex of South of Russia, industrial and agricultural regions, economic consequences of COVID 19, industrial development trends

\section{INTRODUCTION}

In early 2020, the Russian economy faced the need to adapt to new conditions and development factors, caused by the spread of COVID-19, which led to the suspension of

\footnotetext{
*Corresponding author: batmanovavv@volsu.ru
}

DOI: $10.5937 /$ sjm16-28723 
the activities of a significant part of industrial enterprises in the regions and a considerable change in the competitive situation in industrial markets. The growing problems for the industry are connected with disruptions in supply chains (both with suppliers and with consumers), as well as a drop in demand for durable goods.

At the same time, in various industry segments, the level of influence of pandemic factors, the scale of the problems and the consequences accompanying them differ due to the systemic complementary effects of the accumulated economic potential, as well as differences in the applied supporting and limiting state measures. In this respect, there is a need for scientific understanding of the emerging trends in the development of regional industries, analysis of the prospects for their development and the associated risks in reasonable decision making which help to level negative consequences and effectively use the existing opportunities.

According to the position of the authors, the prospects for the development of the industries of the regions are determined, on the one hand, by the balance of market selfregulation and state regulation of processes of support of the sustainability of industrial enterprises in a pandemic, on the other hand, by the accumulated economic potential and adaptive capabilities of the industrial complex of the region itself, proving the ability to continue its work in new economic realities. The purpose of this article is to determine the prospects and identify the risks of industrial complex development of the South of Russia in the conditions of the trends appeared as a result of the pandemic. The subject of research is the possibility to adapt of the industrial complex of the South of Russia, determined by its social and economic potential, as well as by the support measures provided by government.

\section{LITERATURE REVIEW. METHODS OF RESEARCH}

The papers of many domestic and foreign scientists are devoted to the study of the economic potential of regional industrial complex, the study of its rational sectoral structure, as well as the development of adequate assessment tools. Thus, fundamental studies of the economic potential of regional industrial systems, factors and determinants are presented in the papers of Grinberg (2007), Ovchinnikov and Ketova (2016), Mitrofanova \& Chernova (2019), Grebenkin (2020), Chernova \& Mitrofanova (2020), and in some other research made by Russian authors.

The problem of economic crises caused by non-economic factors, including epidemics and pandemics, is not new to world science. In particular, the economic consequences of various epidemics were studied by Adelman and Adelman (1959), Lee and McKibbin (2004), Pilipenko (2011), Bloom et al. (2018) and a number of other researchers.

As for the study of the economic consequences of COVID-19, the papers on this issue appeared already in the spring of 2020. They examine the key macroeconomic policy measures needed to level the direct and indirect negative effects of the pandemic and overcome the crisis, and examine the implications of COVID-19 for various industry segments of national economies (Pandemic COVID-19, 2020; Iacus et al., 2020; Surico \& Galeotti, 2020).

Of course, being in the pandemic, it is rather difficult to speak about the complete picture in terms of the effectiveness of 
certain management decisions and industrial development strategies. At the same time, it is already necessary to study various scenarios for potential use of industrial complexes, as well as various approaches of regional authorities to their support.

The modern economic crisis, which has no analogues in world practice, financial and real markets collapsed almost simultaneously, challenging many existing theoretical approaches that could stop the rapid development of the crisis caused by COVID-19 in economic systems. The scientific community almost unanimously declares the "failures" of a number of economic theories (Armantier et al., 2020; Baddeley, 2020; Fleming et al., 2020). This situation leads to the scientific rethinking of the principles of industrial policy, identifying the features of the response of regional industry to emerging shocks, and understanding the internal sources of economic growth.

\section{MATERIALS AND METHOD (MODEL)}

The basic methodological position of the prospects for the development of regional industrial complexes is the theory of shocks, according to which the indicated shocks are identified by means of non-price determinants that shift the curves of aggregate demand and aggregate supply, leading to a change in structural ties and forcing the market to adapt to these changes. This premise, which is the theoretical basis of this article, makes it possible to place at the center of the system of cause-and-effect relationships a set of factors that reduce business activity in a pandemic, which is considered as an economic shock that forms new trends in industrial development.

Taking into account the most important feature of the negative effects of the COVID19 pandemic i.e. the disruption of interregional relations between the participants in the formation of value chains as a result of the closure of regional borders due to the epidemiological threat, the search for the solutions to maintain sustainable development of regional industry will be carried out to a greater extent from the standpoint of the endogenous approach. In compliance with this concept, the authors focus their research on internal reserves of growth in order to identify how to respond properly to troubles with manufacturing and supply chains caused by the epidemic.

In the conditions of significant differentiation of economic potentials of regional industry, the consequences determined by the factors of the pandemic have different duration, strength and direction. It should be noted that despite a considerable diversity of national industrial policies, there are many common features in approaches to management of the development of industrial systems in regions which are close in specialization. The choice of Krasnodar Krai, Volgograd and Rostov regions as the object of study is explained by the fact that these regions of the Southern Federal District are the leaders in industrial production in the South of Russia. At the same time, we mention that Rostov region and Krasnodar Krai simultaneously have significant areas of agricultural production, what determines the specificity of regional industries. In these regions there are a significant number of agricultural engineering enterprises, firms for agricultural products' processing. Therefore, the identification of trends, prospects and risks of the development of industrial 
complexes of Southern Russian regions in the context of the pandemic may present a certain interest for countries with regions of industrial and agrarian types.

The conducted research includes the following main stages: a) description of the accumulated economic potential of the industrial complex of the South of Russia; b) assessment of pandemic impact on the industry of the regions; c) analysis of measures of state support for the regional economy; d) estimation of prospects and risks of regional industrial development, taking into account the adaptive capabilities of their industrial complex, as well as its ability to continue its functioning in the new economic conditions.

The study covers the time period of the first wave of the pandemic in Russia (April September 2020).

To characterize the accumulated potential of the industrial complex of the South of Russia, the following methods were used: analysis of statistical data, descriptive analysis, analysis of other sources of secondary information.

To assess the impact of pandemic factors on the industry in the region, an integral sensitivity indicator (ISI) was used (eq. 1), which is determined by means of the distance method:

$I S I=\sqrt{\sum_{i=1}^{n}\left(1-I_{i}\right)^{2}}$

$n$ - number of indicators,

$I_{i}$ - index of change of the i-th indicator, calculated as $\mathrm{xm} / \mathrm{x} 0$, $X_{m}$ - value of the indicator in the period of development of the crisis situation under analysis, $x_{0}$ - base value of the index.
This indicator shows the sensitivity of the state of the economic system to external impacts. The higher its value, the more sensitive the system, the less is its ability to adapt.

The indicators characterizing the state of the regional industry were chosen out from the list of indicators of the monthly Monitoring of the economic situation in the regions in the context of the pandemic, conducted by the Federal State Statistics Service. The following indicators were selected for the analysis: Industrial production index; Shipment of industrial goods of our own production; Producer price index for industrial goods (Information for monitoring the social and economic situation of the constituent entities of the Russian Federation, 2020).

The selected indicators are unidirectional; their growth is characterized by an increase in the sustainability of the development of industrial complex.

The values of the corresponding indicator were taken as the basis for the same period of the previous (2019) year in order to take into account possible seasonal fluctuations in industrial production. The information base for the study was the data of the Federal State Statistics Service of the Russian Federation. To characterize the social and economic situation in the regions before the start of the pandemic, the data reflected in the statistical yearbook "Regions of Russia" (Regions of Russia. Social and economic indicators 2020, 2020) were systematized and processed.

When analyzing anti-crisis measures of state support during the pandemic, documents of federal executive authorities (national level) and authorities of the constituent entities of the Russian Federation (regional level) were used. 


\section{RESULTS}

\subsection{Potential of industries of South of Russia}

The main indicator characterizing the regional sectoral structure is gross regional product (GRP). Despite the fact that the regions of the South of Russia are traditionally classified as regions with agricultural specialization (agricultural production has about $11-13 \%$ in the GRP structure (Table 1), Volgograd and Rostov regions, as well as the Krasnodar Krai, in recent years have been gradually restoring and developing industrial manufacturing, as it is shown in Fig. 1 and 2. At the same time, it should be noted that the transit nature of resource and commodity flows in the regions, due to their geographic location, is reflected in the high share of GRP of the "transportation and storage" activity (Mitrofanova et al., 2019a).
At the beginning of 2020, the structure of manufacturing was dominated by the production of food and drinks, production of petroleum products, metallurgical production, as well as the production of machinery and equipment (Fig. 3). As we can see from the presented data, despite the recovery of the industrial sector of the economy of the South of Russia, the main drivers of growth remain connected with the industry of the first processing (oil sector, metallurgy, food industry) and are focused on the use of their own resources.

In the field of high-tech business, Southern Russian regions are among the outsiders. According to Federal Service for State Statistics, the volume of production of innovative products in the region does not exceed $6 \%$ and in the last 4 years has a steady downward trend. The innovative activity of organizations in the field of technological innovations decreased from $9.2 \%$ in 2015 to 2018 to $7.7 \%$. The growth

Table 1. GRP structure of Southern Russian regions (Regions of Russia. Social and economic indicators 2020, 2020), \%

\begin{tabular}{lccc}
\hline \multicolumn{1}{c}{ Indicator / Regions of the South of Russia } & $\begin{array}{c}\text { Volgograd } \\
\text { region }\end{array}$ & $\begin{array}{c}\text { Rostov } \\
\text { region }\end{array}$ & $\begin{array}{c}\text { Krasnodar } \\
\text { Krai }\end{array}$ \\
\hline Agriculture and fishing & 10.5 & 10.2 & 10.6 \\
Mining & 6.4 & 1.2 & 1.2 \\
Manufacturing industries & 27.7 & 20.9 & 11.7 \\
Production of electricity, gas and steam, air conditioning & 2.5 & 4.5 & 2.3 \\
Water supply and sanitation & 0.7 & 1.0 & 0.9 \\
Construction & 6.1 & 5.7 & 6.9 \\
Commerce & 13.2 & 17.8 & 17.3 \\
Transport and storage & 5.5 & 7.8 & 16.3 \\
Hotels and catering & 0.8 & 1.3 & 3.5 \\
Information and communication & 2.5 & 2.2 & 2.5 \\
Financial activities & 0.3 & 0.3 & 0.3 \\
Real estate deals & 3.7 & 8.1 & 6.0 \\
Professional, scientific and technical activities & 3.4 & 2.8 & 2.5 \\
Administration & 1.7 & 1.7 & 2.6 \\
Public administration & 5.5 & 4.8 & 4.3 \\
Education & 3.6 & 3.5 & 3.3 \\
Healthcare & 4.6 & 5.1 & 5.4 \\
Culture, sports, leisure and entertainment & 0.7 & 0.6 & 1.6 \\
Other services & 0.6 & 0.5 & 0.8 \\
\hline
\end{tabular}




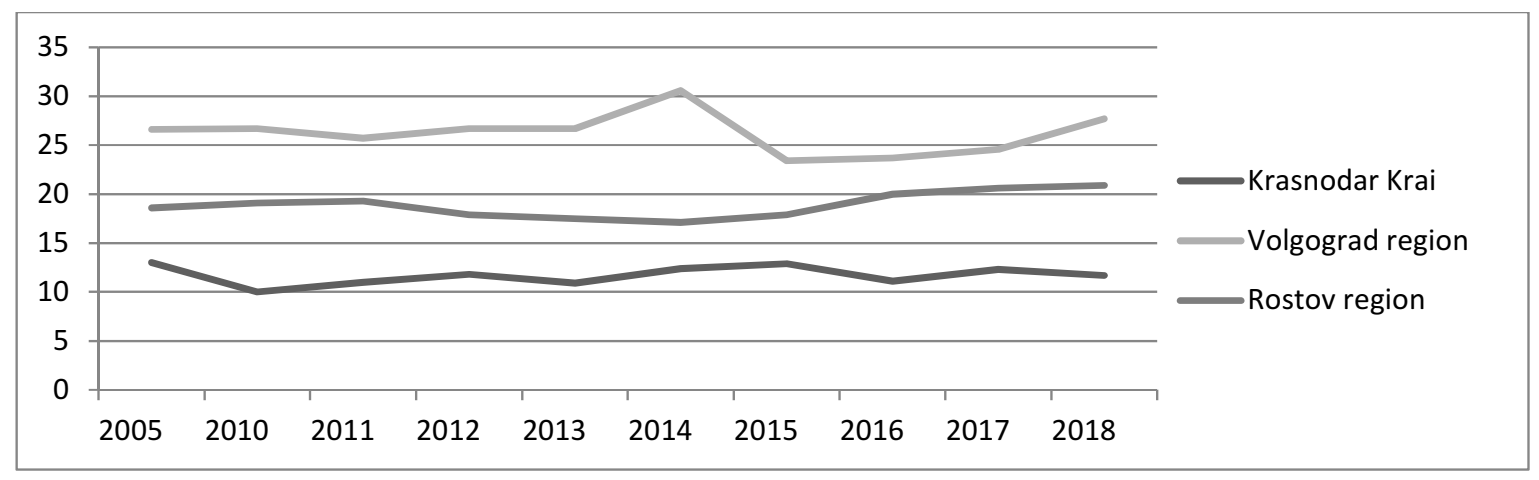

Figure 1. Dynamics of changes in the share of manufacturing in the GRP of southern Russian regions (Regions of Russia. Social and economic indicators 2020, 2020), \%

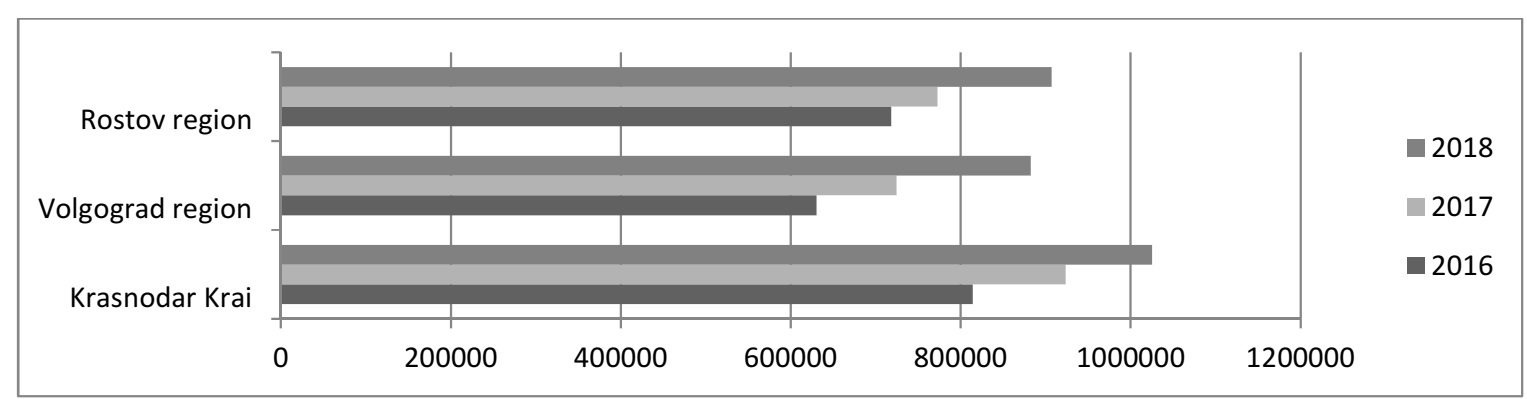

Figure 2. Volume of shipped goods of own production, works and services in manufacturing (Regions of Russia. Social and economic indicators 2020, 2020), million rubles

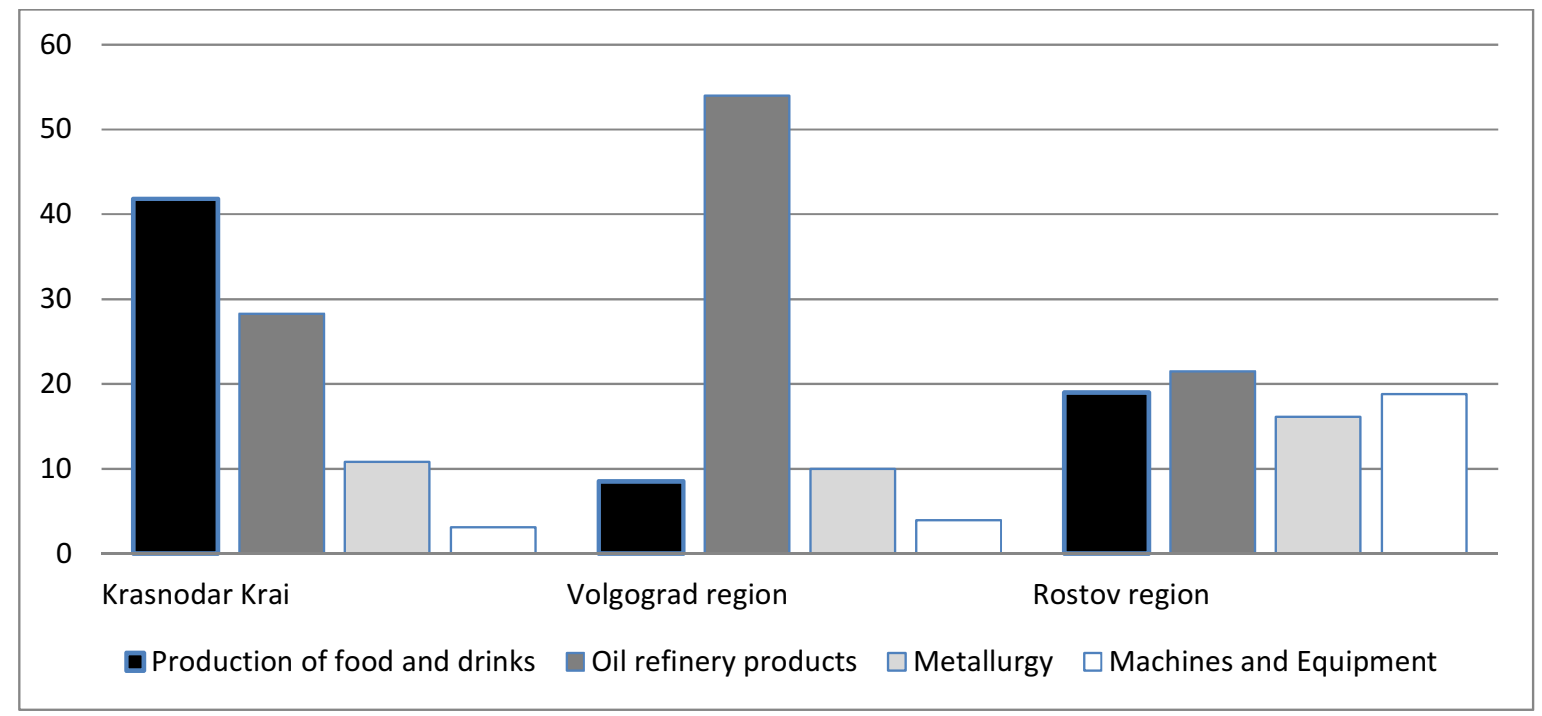

Figure 3. Share of shipped products according to the main types of economic activity in its total volume in the manufacturing sector (Regions of Russia. Social and economic indicators 2020, 2020), \% 
rates of the used advanced technologies are significantly lower than in average for Russia and since 2010 have been in average about 3\%. The share of products of high-tech and knowledge-intensive industries is about $20 \%$ and over the past 5 years this indicator has remained practically unchanged, lagging behind the average Russian dynamics. Taking this fact into account, we can say that the problems with stocks and supplies of raw materials for high-tech production will not directly affect the economy of the regions under analysis.

The trend of industrial development of Southern Russian regions in recent years became the integration of large, small and medium-sized innovative companies into clusters. The most famous industrial clusters in the South of Russia are Territorial Cluster of Helicopter Construction, National Industrial Cluster of Agricultural Engineering, Volgodonsk Industrial Cluster of Nuclear Engineering, and Chemical and Pharmaceutical Cluster. The advantage of the cluster form of business organization is the ability to form complete technological chains (closed production cycles), which can significantly reduce the degree of dependence of companies on interregional relations and be less dependent on breaks in the supply system (Mitrofanova et al., 2019b; Mitrofanova et al., 2020). Thus, by the beginning of the economic crisis caused by the rapid spread of the coronavirus, the industrial complex of the South of Russia had significant potential in the raw materials sector (agricultural processing, oil refining, metallurgical production). Innovative and high-tech production in the region was provided by the activities of integrated structures (clusters) in the field of helicopter construction, agricultural and nuclear engineering.

\subsection{Pandemic impact on development of industrial complex of Southern Russia}

The Covid-19 epidemic caused the economic crisis which influenced the economy of the South of Russia in April 2020. At that time the self isolation regime was introduced and the activities of a number of enterprises were suspended. Only industrial enterprises from a special list continued to operate in Rostov Region and Krasnodar Krai. All industrial enterprises kept working in Volgograd region. The transportation of citizens was restricted in all regions. People were allowed to leave home only to work, to visit elderly relatives, as well as grocery stores and pharmacies. As a result of the decline in business activity (Fig. 4), supply chains were broken, flows of resources and capital were reduced, and

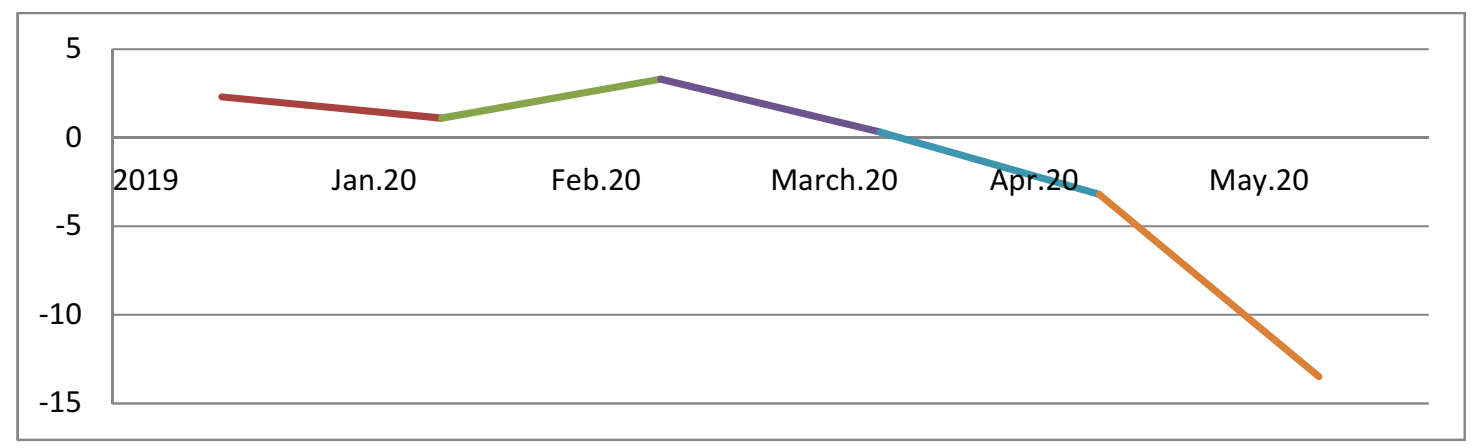

Figure 4. Business activity index for Russian industry (Business picture for May, 2020). 
effective demand fell.

As a result of business activity decline (Fig. 4), supply chains were destroyed, flows of resources and capital reduced, and effective demand fell. The negative trends in the industry are evidenced by a decrease in the volume of shipped goods by railroad (by $5-6 \%$ ), as well as a decrease in energy consumption (the average daily economic activity decreased by $16 \%$ ). Despite the fact that industrial production as a whole suffered less from the coronavirus than the service sector, the vulnerability of industrial enterprises was also quite high due to the fact that a) the bulk of industrial processes cannot be transferred into an online format; b) it is not always possible to ensure social distancing in the workplace.

A negative trend in the industry shows a decrease of shipment volumes at railways (5-6\%), and reduced energy consumption (average economic activity decreased by $16 \%$ ). According to the results of a business survey conducted by the Chamber of Commerce and Industry of the Russian Federation within the framework of the Country Business Barometer project, $8 \%$ of respondents announced that their business was finally closed, and another $8 \%$ believe that it is in the process of closing.

Despite the fact that industrial production as a whole suffered less from the coronavirus than the service sector, the vulnerability of industrial enterprises also turned out to be quite high due to the fact that: a) the bulk of production processes cannot be translated into an online format; b) it was not always possible to ensure social distancing in the workplace.

At general negative trends in the development of the economic situation in the Southern Russian regions, the degree of impact of pandemic factors on the state of their industrial complexes varied in dependence on the sectoral structure of the economy, as well as the accumulated industrial potential. The initial data for the analysis are presented in Table 2 .

The calculation results of the integral indicator of sensitivity in dynamics for each region are presented in Table 3.

In the study of the impact of the pandemic on the development of the industrial complex of the region, it is not so much the absolute value of the integral sensitivity indicator that matters, but the tendency of its change (Fig. 5 ), which characterizes various scenarios of the development of the economic situation.

Using the data shown in Figure 5, there are three possible scenarios for the development of the adaptive capabilities of regional industry to changing economic conditions in the South of Russia:

a) low rates of adaptation of the industrial complex in comparison with a high degree of sensitivity of the regional economy to pandemic factors (Krasnodar Territory);

b) worsening of economic problems as the pandemic develops together with the manifestation of adaptive capabilities as restrictions are lifted and state support is provided (Volgograd region);

c) a high level of adaptation of the regional industry to the new realities against a low sensitivity to pandemic factors (Rostov region).

The industry of Krasnodar Krai and the Volgograd region turned out to be the most sensitive to the factors of the pandemic among the Southern Russian regions. This situation is explained by the fact that the industrial potential of these regions is mainly associated with the production of petroleum products. The situation on the energy market during the pandemic caused serious risks for the development of industries in these 
regions.

The industry of Krasnodar Krai during the first wave of the pandemic was unable to adapt fully to the new conditions. The woodworking and furniture industries have a significant share in the structure of the manufacturing industry of Krasnodar Krai. Currently, more than 3.5 thousand enterprises with a total number of employees over 6 thousand are engaged in these industries. Most of these enterprises were among the victims of the pandemic as a result of the influence of continued restrictive measures on the activities of potential buyers i.e. companies in the tourism and hospitality business, health resorts, and shopping centers.

A significant role in the support of the industrial complex of the region had the food industry, which practically did not feel the consequences of the crisis during the pandemic. Due to its important role in the life support system, most enterprises in this industry did not stop their production.

Table 2. Indicators characterizing the state of industry in the regions of South of Russia (compiled from the source: Information for monitoring the social and economic situation of the constituent entities of the Russian Federation, 2020).

\begin{tabular}{llcccccc}
\hline Region & Indicator & April & May & June & July & August & September \\
\hline & $\begin{array}{l}\text { Index of industrial } \\
\text { production }\end{array}$ & 111.3 & 97.3 & 90.4 & 95.1 & 87.4 & 93.3 \\
$\begin{array}{l}\text { Krasnodar } \\
\text { Krai }\end{array}$ & $\begin{array}{l}\text { The index of industrial } \\
\text { shipments of goods of own } \\
\text { manufacture }\end{array}$ & 84.3 & 77.9 & 79.9 & 81.1 & 83.9 & 88.7 \\
& $\begin{array}{l}\text { Industrial Producer Price } \\
\text { Index }\end{array}$ & 102.0 & 100.9 & 100.5 & 101.7 & 102.4 & 104.1 \\
& $\begin{array}{l}\text { Industrial production index } \\
\text { Shipment index for }\end{array}$ & 88.5 & 94.5 & 94.6 & 104.9 & 103.1 & 106.7 \\
$\begin{array}{l}\text { manufactured goods of own } \\
\text { production }\end{array}$ & 92.8 & 89.2 & 107.0 & 103.9 & 98.8 & 105.3 \\
region & $\begin{array}{l}\text { Industrial Producer Price } \\
\text { Index }\end{array}$ & 101.0 & 100.9 & 100.6 & 101.8 & 102.9 & 103.4 \\
\hline $\begin{array}{l}\text { Industrial production index } \\
\text { Volgograd }\end{array}$ & $\begin{array}{l}\text { Shipment of manufactured } \\
\text { goods of own production } \\
\text { region }\end{array}$ & 89.4 & 78.4 & 84.9 & 96.4 & 100.6 & 93.8 \\
& $\begin{array}{l}\text { Industrial Producer Price } \\
\text { Index }\end{array}$ & 85.8 & 84.9 & 92.4 & 97.5 & 97.3 & 96.7 \\
\hline
\end{tabular}

Table 3. The value of the integral index of sensitivity (ISI)

\begin{tabular}{lllllll}
\hline & April & May & June & July & August & September \\
\hline Krasnodar Krai & 0.194 & 0.222 & 0.223 & 0.196 & 0.206 & 0.138 \\
Rostov region & 0.136 & 0.122 & 0.089 & 0.065 & 0.044 & 0.092 \\
Volgograd region & 0.180 & 0.289 & 0.196 & 0.078 & 0.072 & 0.104 \\
\hline
\end{tabular}




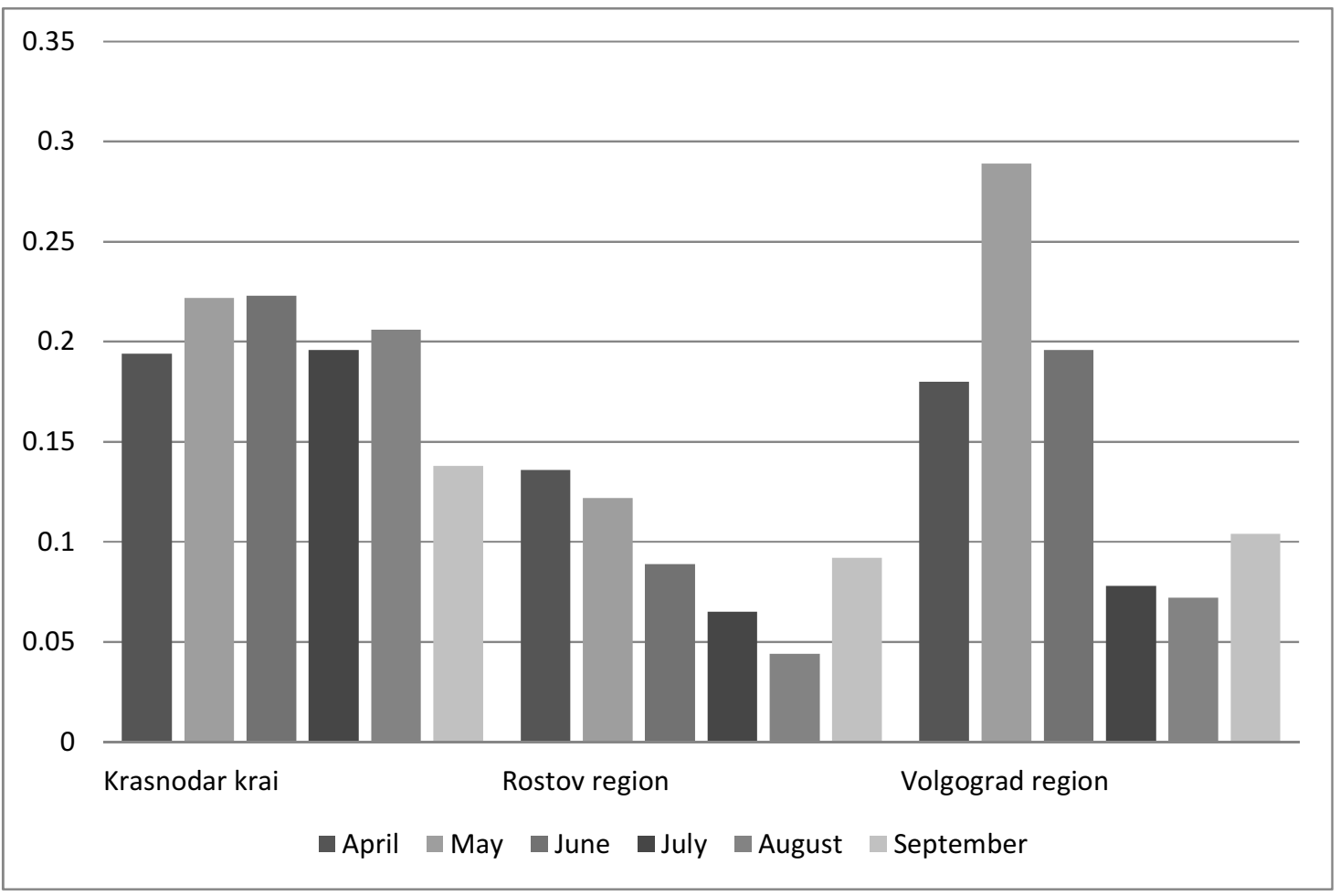

Figure 5. Change in the integral indicator of the sensitivity of industry in the regions of South of Russia

Moreover, due to a high demand for food products during the pandemic, agricultural processing enterprises retained and strengthened their stability.

During the pandemic, the Korenovsky plant (Krasnodar Krai) signed five agreements with investors in the agroindustrial complex and food industry for a total of 2 billion rubles, three agreements were concluded for the modernization of industrial complexes and the construction of irrigation systems. In total, 98 protocols of intent in the food industry (including export contracts) totaling 33.2 billion rubles were signed in Krasnodar Krai during the pandemic.

In Volgograd region, at the beginning of the pandemic, the industrial production index fell by 12\% compared to May 2019. Due to technological peculiarities, the metallurgical industry in Volgograd region continued to work, since a complete stop of production would lead to huge financial losses. Nevertheless, taking into account the export orientation of raw materials industries, amid the closure of borders and the fall in world prices for metals, production at enterprises fell by $50-70 \%$. Thus, the production capacity of metallurgical plants in Volgograd region is currently $20-30 \%$ of the maximal one, and $14 \%$ of workers are on forced leave (about 3600 people). The machine-building industry, which is focused on the oil and gas sector, was significantly affected in the region. Some improvement in industrial production took place only when the restrictions were removed.

The industry of Rostov region turned out to be less sensitive to pandemic factors, which is largely connected with the presence 
of agricultural engineering enterprises in its structure, which showed growth. For example, in Rostov region, the production of agricultural machinery and equipment increased by $27 \%$, vehicles, trailers and semi-trailers grew by $38 \%$. The mining production of Rostov region did not also stop due to technological reasons and safety considerations. However, in the first five months of 2020, the industrial production index in Rostov region decreased by $2.2 \%$. The most noticeable decline was in the extraction of minerals, the decline was $18.6 \%$. In addition, the production of electricity, gas and steam decreased by $12.4 \%$. Also, metallurgical production decreased by $10.3 \%$, and the production of computers, electronic and optical products reduced by $20.3 \%$.

In general, it can be noted that the industrial complex of Rostov region which is largely focused on agriculture was the most resistant to pandemic factors.

Another important factor in the higher degree of adaptation of the industry in this region is a high level of development of regional innovation system, which makes it possible to transfer business processes and business communications online.

\subsection{Government support for industry during pandemic}

In order to reduce the negative impact of the pandemic on industrial enterprises, the government suggested support measures (Fig. 6) and made up a plan of priority measures to ensure the sustainable economic development amid the worsening situation because of coronavirus infection. The entire set of measures can be divided into the following categories: tax support; financial and credit support; property maintenance support; administrative support; promotion of employment.

These measures are meant for organizations included in the list of the most affected industries, which, in particular, include the firms which are not connected with industrial production (trade, services,

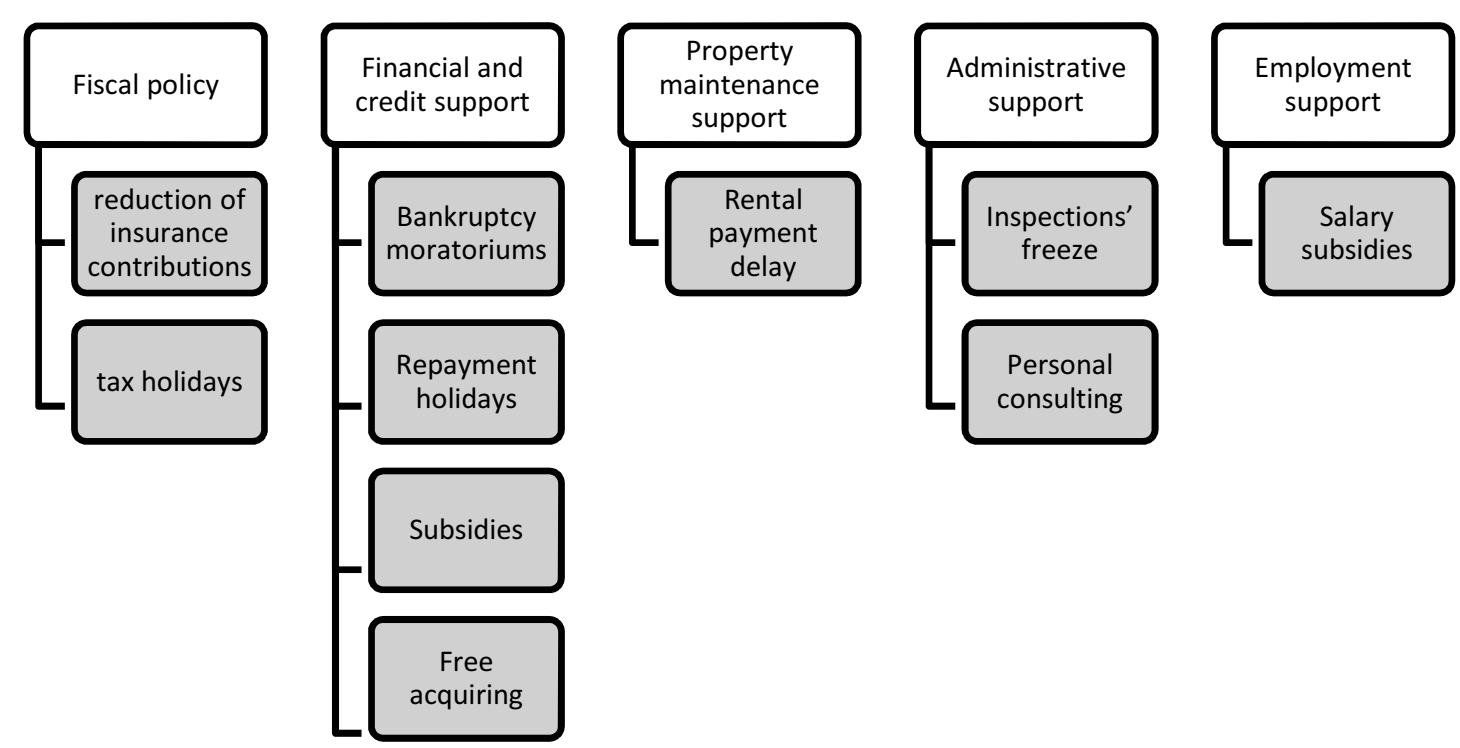

Figure 6. Government support measures for business in Russia 
air and road transport, beauty industry, etc.) (The list of the most affected industries, 2020). In addition, in order to stimulate hightech start-ups that develop solutions based on breakthrough technologies in the industry, since March 2020, a support program for the Skolkovo Foundation and I-Teco IC Promtech has been in effect, which provides support to areas of remote enterprise management technologies.

Taking into account significant differences in the sectoral structure of territories, and systemic types of activities, the regions were given the right to make the sets of support measures individual.

The regions made their own lists of industries that could count on government support and assistance. Along with this, the lists of system-forming enterprises were made (this list is largely formed by industrial enterprises) that have a significant impact on the economy and social stability, and which, due to the mentioned specificity, continued their work during self-isolation.

Let us characterize the main decisions of regional authorities in the South of Russia in terms of support of industrial enterprises.

The main attention in Rostov region was paid to support of regional agro-industrial complex. 5.2 billion rubles were allocated, including 2.2 billion rubles from the regional budget. In addition, it is planned to allocate an additional 240 million rubles for the modernization of food and processing industries and 75 million rubles to stimulate the production of cattle meat.

In Krasnodar krai, furniture and woodworking industries were among the most affected industries. In accordance with the governor's decree, enterprises in these industries were allowed to work, despite self-isolation.

In Volgograd region, investment projects were specifically emphasized. Taking into account the fact that metallurgical production and mechanical engineering in the region are presented by large companies for which direct support is not allocated, the Industrial Development Fund offers preferential terms for the implementation of investment projects in priority areas of development of Volgograd region. In particular, businesses can take advantage of concessional project financing at 1\%, 3\% and $5 \%$ per annum for a period of up to 5 years in the amount of 5 to 100 million rubles. In addition, the investor gets tax incentives for corporate property tax, as well as reduced tax rates for corporate income tax. It is also planned to launch an anti-epidemic program in the region, aimed at financing those who are ready to produce equipment and products for the detection, prevention and treatment of epidemic diseases, as well as those who produce personal protective equipment, medicines and medical devices.

It is difficult to assess the effectiveness of these support measures for the industrial complex of the region at the present time, taking into account the ongoing pandemic. This aspect of the study can be seen as an area for future studies.

\section{DISCUSSIONS}

Despite a negative connotation of social and economic forecasts, it is assumed that the trends in industrial business development that appeared as a result of the pandemic are creating new opportunities, which can be used when gaining significant competitive advantages in the market. Systematizing these trends, we can say that in general they are expressed in the adaptation of companies to the current economic situation and in the 
strengthening their market positions. In particular, the following key areas can be identified that have the greatest impact on the development of the regional industrial complex:

a) change of business strategies of small and medium-sized industrial enterprises in favor of expanding partner networks for maintenance of the existing realities, as well as to compete with industrial giants;

b) changes in the product range of companies with a focus on the production of essential goods, as well as protective equipment;

c) transfer of a number of business processes from off-line to on-line with accompanying changes in the business serving the industrial business (marketing, logistics, retail chains, etc.);

d) re-equipment of workplaces with the provision of spacing requirements, changes in health and safety requirements.

The prospects for the development of industries of the South of Russia within the framework of the indicated trends are largely determined by the extent to which enterprises can implement and accelerate the digitalization processes in production. The basic conditions for converting business processes into digital format are: availability of equipment with numerical control; availability of an automated planning and accounting system; reserve of employees capable of being responsible for an innovative field of activity.

However, according to estimates made by the Ministry of Industry and Trade of the Russian Federation together with "Cifra" (Tsifra) company, only $14 \%$ of enterprises in the Russian industry fulfill the first condition (mainly, these are enterprises of the aircraft industry, tool engineering). In mechanical engineering, this indicator is about $10 \%$. At the same time, it should be noted that the costs of digitalization and the development of IT infrastructure of domestic industrial companies do not exceed $1 \%$ of their budget. The situation is somewhat better with the availability of automated planning and accounting systems at industrial enterprises. These systems are available in about $80 \%$ of companies. As for the staffing of digitalization processes, in 61 cases out of 100 , the enterprises do not have the position of the director for innovation or the digital economy, a third of these responsibilities are divided between various employees, and only $6 \%$ of companies have this position.

The main risks in the development of the industrial complex of the region (both raw materials and non-raw materials production), along with an insufficient degree of readiness for digital transformations, are associated with a demand shock and a supply shock, which displays itself in the break of supply chains.

The development of the sphere of nonresource (manufacturing) production is associated with the risk of a decrease in effective demand as a result of the fact that consumers reduce their expenses for the purchase of industrial goods (furniture, clothing and footwear, cars, etc.) at a decrease in their incomes and the uncertainty of the economic situation. At the same time, it is big business that experiences the greatest difficulty in this regard.

The development of the commodity segment of the industry is connected with risks of falling energy prices, which, according to the World Bank, will lead to a complete or partial stop of activities in mining (Industry and Environmental Impact of the COVID-19 Pandemic, 2020).

It should be noted that the gap in value chains will be less significant for enterprises 
in industrial clusters in the region with a complete production cycle. In addition, as it was mentioned earlier, the quarantine measures practically did not affect the export volumes of agricultural products in Krasnodar Krai and Rostov region, which have the 2 nd and 3rd places in this indicator in the country. The production and technological chains are largely transformed against the background of growing demand for personal protective equipment and medical devices and are expressed in the reequipment of a number of production enterprises. At the same time, the greatest prospects in this direction are associated with the production of commodities that are critical in a pandemic and in the postpandemic period. Enterprises that can closely coordinate with the public sector in this activity will receive tax preferences, as well as a guaranteed order for production. It is worth mentioning that such a conversion will be important for chemical and food industries, mechanical engineering, and energy.

It goes without saying that all the prospects for the development of industrial complexes in the South of Russia are connected with the introduction of innovations. However, the risks of realization of innovative industrial business projects are associated with a lack of cash reserves. The share of unprofitable enterprises in industrial production in Southern Russian regions (Table 4) proves that the financial safety reserve is insufficient to continue working.

This situation leads to significant economic tension in enterprises, prevents investing in new growth opportunities. In addition, the enterprises need additional financial resources to meet new labor safety requirements, including re-equipment of workplaces (to ensure distancing), retraining and advanced training of workers.

\section{CONCLUSION}

The consequences of the COVID-19 pandemic affected all sectors of the economy of the South of Russia, and to a greater extent, the pandemic influenced negatively small and medium-sized businesses and the service sector. However, large industrial enterprises are also suffering from the pandemic because of production breaks and disruption of supply chains, and a reduction in resource flows. All this is complicated by a decrease in effective demand for industrial products. It should also be borne in mind that so far there is only limited and fragmented data on the impact of the COVID-19 pandemic crisis on the activities of industrial companies.

The scientific contribution of the authors of this article to the study of the issues of industrial complexes development in the regions is expressed in the assessment of the first results of the influence of pandemic

Table 4. Share of unprofitable enterprises in the Southern Federal District, \%

\begin{tabular}{lccc}
\hline Region & mining & manufacturing & $\begin{array}{c}\text { production of electricity, gas } \\
\text { and steam, air conditioning }\end{array}$ \\
\hline Krasnodar Krai & 40.9 & 35.1 & 50.0 \\
Volgograd region & 18.2 & 36.7 & 56.7 \\
Rostov region & 51.7 & 27.5 & 39.6 \\
\hline
\end{tabular}


factors on the economy of agro-industrial and old industrial regions, in the analysis of the main trends in the development of regional industrial complexes and in the study of the peculiarities of their response to emerging shocks. When substantiating the directions for the development of anti-crisis measures of industrial policy, the authors search for the internal factors of economic growth, which are a powerful source of maintaining a dynamic equilibrium in the development of industrial systems. The discussion of the lessons from the experience of the Southern Russian regions allows us to develop measures to increase the sustainability of the development of industrial systems in other regions and countries of agro-industrial specialization.

The first results of the study showed that mining industries, oil refining, and metallurgy were the most affected in the South of Russia, while machine-building and food industry enterprises not only remained stable, but also had growth. At the same time, it is obvious that government support allows enterprises to keep working. However, the prospects for the strategic development of the industrial complex of the region connected with the possibility of enterprises to optimize their business processes and organizational structures through the introduction of information (digital) technologies and automation technologies.

During the pandemic, it became obvious that most of the problems can be solved through the introduction of digital tools for the transformation of industry, the concentration of management, financial and technological resources for a large-scale restructuring of the entire production and technological cycle of enterprises' work, i.e. starting from the analysis of market needs to production, promotion and direct sales of products. These processes lead to the need for training and professional growth of employees, changes in their working conditions. At the same time, as studies show, many companies plan to retain the ability to work remotely for certain categories of employees in the postpandemic period.

However, these measures are constrained by the continuing supply and demand shocks, as well as the insufficient economic potential of the industrial business of Southern Russian regions. The greatest prospects for the industrial development of the South of Russia are associated with the agro-industrial complex, as well as the military and industrial complexes.

Taking into account that the COVID-19 pandemic is still ongoing, it is currently difficult to assess the full scale of its consequences for industrial development, therefore, the further direction of the authors' research is connected with their assessment in the medium and long term.

\section{Acknowledgments}

The publication was prepared as part of the State Assignment of the Southern Scientific Centre of the Russian Academy of Sciences, No. of state registration of the project AAAA-A19-119011190184-2.

\section{References}

Adelman, I., \& Adelman, F. (1959). The Dynamic Properties of the Klein-Goldberger Model. Econometrica, October, 27 (4), 596625.

Armantier, O., Koşar, G., Pomerantz, R., Skandalis, D., Smith, K., Topa, G., \& Van der Klaauw, W. (2020). Inflation Expectations in 


\title{
ТРЕНДОВИ, РИЗИЦИ И ПЕРСПЕКТИВЕ ЗА РАЗВОЈ ИНДУСТРИЈСКОГ КОМПЛЕКСА ЈУГА РУСИЈЕ У НОВОЈ ЕКОНОМСКОЈ РЕАЛНОСТИ
}

\author{
Inna V. Mitrofanova, Olga A. Chernova, Victoria V. Batmanova, \\ Oksana Yu. Trilitskaya
}

Извод

Догађаји изазвани комплексном кризом која је постала евидентна у регионалним економијама као резултат ширења КОВИД-19 утицала су на прерађивачку индустрију југа Русије. Сврха овог чланка је да идентификује и анализира перспективе за одрживи развој индустрије на југу Русије у контексту нових економских трендова. Методолошка основа студије заснована је на теорији шокова, која је омогућила да се у центар система узрочнопоследичних веза стави скуп фактора смањења пословне активности, који се сматрају шоковима који формирају нове трендови развоја. Анализа је открила присуство проблема прекида производње и прекида ланаца снабдевања, смањења токова ресурса, као и смањења ефективне тражње за индустријским производима. Према мишљењу аутора, изгледи за развој индустријског комплекса региона повезани су са балансом саморегулације тржишта и државне регулације, а такође су одређени акумулираним потенцијалом регионалне индустрије и расположивим адаптивним способностима.

Кључне речи: индустријски комплекс југа Русије, индустријски и пољопривредни региони, економске последице КОВИД-19, трендови индустријског развоја

Times of COVID-19. Federal Reserve Bank of New York. Liberty Street Economics. Retrieved from: https://libertystreeteconomics.newyorkfed.org/2020/05/inflationexpectations-in-times-of-covid-19.html

Baddeley, M. (2020). Hoarding in the age of COVID-19. Journal of Behavioral Economics for Policy. Society for the Advancement of Behavioral Economics (SABE), 4 (S), 69-75.

Bloom, D.E., Cadarett, D., \& Sevilla, J.P. (2018). New and resurgent infectious diseases can have far-reaching economicrepercussions. Finance \& Development, 55 (2), 46-49.

Business picture for May 2020 (2020). Ministry of Economic Development of the Russian Federation. Retrieved from: https://www.economy.gov.ru/material/file/0a 16c1bc10412bb6dcabfc834301154b/200618 _.pdf

Chernova, O. A., \& Mitrofanova, I. V. (2020). Economic Policy of Agro-Industrial Regions of the South of Russiain the Conditions of COVID-19 (in Russian). Regional Economy. South of Russia, 8 (3), 150-162.

Fleming, M.J., Sarkar, A., \& Van Tassel, P. (2020). The COVID-19 Pandemic and the Fed's Response. Federal Reserve Bank of New York . Liberty Street Economics . Retrieved from: https://ibertystreeteconomics.newyorkfed.org/2020/04/the-covid-19pandemic-and-the-feds-response.html

Grebenkin, I.V. (2020). Trends in industrial specialization and dynamics of 
development of Russian regions (in Complex of the South of Russia. In: Russian). Economy of Region, 16 (1), 69- Popkova, E., \& Ostrovskaya, V. (eds.) 83.

Grinberg, R.S. (2007). Structural policy is an uncontested means of the Russian economy modernization (in Russian). Economy of Region, 3, 9-18.

Iacus, S.M., Natale, F., Santamaria, C., \& Vespe, S.S.M. (2020). Estimating and projecting air passenger traffic during the COVID-19 coronavirus outbreak and its socio-economic impact. Safety Science, 129, 104791.

Industry and Environmental Impact of the COVID-19 Pandemic (2020). Department of International and regional cooperation of the JV RF. Retrieved from: http://www.ach.gov.ru/upload/pdf/Covid-19prom.pdf

Information for monitoring the social and economic situation of the constituent entities of the Russian Federation (2020). Retrieved $\begin{array}{lllll}\mathrm{f} & \mathrm{r} & \mathrm{o} & \mathrm{m} & \text { : }\end{array}$ https://rosstat.gov.ru/folder/11109/document $/ 13259$

Lee, J.-W., \& McKibbin, W.J. (2004). Estimating the global economic costs of SARS. In: Knobler, S., Mahmoud, A., Lemon, S., Mack. A., Sivitz, L., \& Oberholtzer, K. (Ed.). Learning from SARS: preparing for the next disease outbreak: workshop summary. National Academies Press (US), Washington (DC).

Mitrofanova, I.V., \& Chernova, O.A. (2019). Reindustrialization of Old Industrial Regions in the South of Russia: Trends, Potential, Risks. Science Journal of Volgograd State University. Global Economic System, 21 (1), 13-27.

Mitrofanova, I.V., Chernova, O.A., Buyanova, M.E., Ivanov, N.P., \& Mitrofanova, I.A. (2019a). Import Substitution Potential of the Agricultural Perspectives on the Use of New Information and Communication Technology (ICT) in the Modern Economy. ISC 2018. Advances in Intelligent Systems and Computing, 726, Springer, Cham. 817-838.

Mitrofanova, I.V., Chernova, O.A., Pyankova, S.G., \& Batmanova, V.V. (2020). Innovative Impact of Import Substitution Processes in the Economy of the South of Russia. In: Inshakova, A., Inshakova, E. (eds.) Competitive Russia: Foresight Model of Economic and Legal Development in the Digital Age. CRFMELD 2019. Lecture Notes in Networks and Systems, 110, Springer, Cham. 49-58.

Mitrofanova, I.V., Sheikin, D.A., Pozhilova, I.V., Yalmaev, R.A., \& Mishieva, A.T. (2019b).'Socio-economic Aspects of Formation and Development of Territorial Clusters in the Context of Global and Russian Institutional Problems. In: Elena G. Popkova (ed.). Conflict-Free" SocioEconomic Systems. Emerald Publishing Limited, 259-275.

Ovchinnikov, V. N., \& Ketova, N. P. (2016). The system-complementary effect of the interaction of the innovation potential and the institutional environment of the region (in Russian). Economy of Region, 12 (2), 537-546.

Pandemic COVID-19. (2020). Mizintseva. M.F. (Ed.) Biology and Economics Interdisciplinary information and analytical collection. Pero Publ, Moscow.

Pilipenko, Z.A. (2011). Shocks and national economic systems: mechanism of destruction of structural relations (in Russian). Economics and Law Issues, 40, 55-60.

Regions of Russia. Social and economic indicators 2020. (2020). Statistical bulletin. 
Rosstat, Moscow.

Surico, P., \& Galeotti, A. (2020). The Economics of a Pandemic: the case of Covid-19. Wheeler Institute for Business and Development. Retrieved from: https:/icsb.org/theeconomicsofapandemic/

The list of the most affected industries (2020). Decree of the Government of the Russian Federation No. 434 of April 3, 2020 and supplemented by the Order of the Government of the Russian Federation No. 961-r of April 10, 2020. Retrieved from: https://base.garant.ru/73846630/ 